\title{
A STUDY ON THE TAXONOMY OF SOME STOLONIFLOROUS SPECIES OF FICUS SUBSECTION SYCOCARPUS (MORACEAE) IN THAILAND AND MALESIA
}

\author{
CORNELIS C. BERG ${ }^{1} \&$ BHANUMAS CHANTARASUWAN ${ }^{2}$
}

\author{
SUMMARY
}

The taxonomy of several, mainly stoloniflorous, Ficus species from Thailand and Malesia is revised resulting in a new species, F. bukitrayaensis C.C. Berg and two new names, F. malayana C.C. Berg $\&$ Chantarasuwan and F. ridleyana C.C. Berg \& Chantarasuwan. Ficus megaleia Corner and F. uncinata (King) Becc. are redefined and F. heterostyla Merr. is reinstated. Ficus arfakensis King and $F$. scortechinii King are reduced to synonyms of $F$. ribes Blume.

Key words: Moraceae, Ficus, stoloniflorous species, Malesia, Thailand.

\section{INTRODUCTION}

Ficus subg. Sycomorus of Thailand and the Malay Peninsula comprises five stoloniflorous (or flagelliflorous) species: Ficus beccarii King, F. heterostyla, F. malayana, $F$. ridleyana and $F$. semicordata Buch.-Ham. ex Sm. Three of them are based on varieties of which two were already regarded as problematical in connection with the preparation of the Ficus treatment for Flora Malesiana (Berg \& Corner, 2005) as varieties in F. uncinata (King) Becc. and F. vrieseana Miq., and because of the differences with the other varieties not included in the Flora Malesiana treatment. Further studies, primarily on behalf of the Flora of Thailand, led to a revision of the stoloniflorous species in this peninsular part of Asia. It also led to the redefinition of F. ribes Blume, a potentially stoloniflorous species in the region and to the re-evaluation of the Bornean material included in F. uncinata.

\section{Stoloniflorous species in Thailand and Peninsular Malaysia}

\section{KEY TO THE OBLIGATORY AND POTENTIALLY STOLONIFLOROUS SPECIES OF THAILAND AND THE MALAY PENINSULA}

1a. Leaves partly subopposite; lamina symmetric or slightly asymmetric . . . . . 2

b. Leaves (sub)distichous; lamina more or less strongly asymmetric . . . . . . . . 3

1) Bergen Museum, University of Bergen, Allégate 41, 5007 Bergen, Norway; Nationaal Herbarium Nederland, Leiden University branch, P.O. Box 9514, 2300 RA Leiden, The Netherlands; e-mail: berg@nhn.leidenuniv.nl.

2) National Science Museum, Technopolis, Khlong 5, Khlong Luang, Pathum-Thani 12120, Thailand; e-mail: bhnashine@yahoo.com. 
2a. Lamina scabrous above $\ldots \ldots \ldots \ldots \ldots \ldots \ldots \ldots \ldots \ldots \ldots$. F. heterostyla

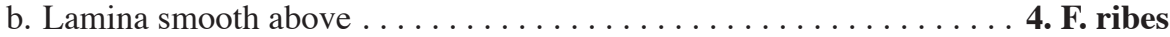

3a. Margin of lamina entire, including the long caudate apex . . . 1. F. beccarii

b. Margin of lamina dent(icul)ate, at least of the acumen . . . . . . . . . 4

4a. Waxy gland in the axil of the basal lateral vein at the broad side of the lamina; basal lateral veins normally $9-15$ pairs; epidermis of petiole flaking off . . . . . .

6. F. semicordata

b. Waxy glands in the axils of some lateral veins in the middle part of the lamina or also in the furcation of lateral veins; lateral veins normally $6-9$ pairs, epidermis

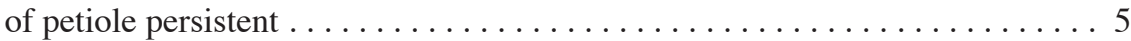

5a. Fig receptacle with numerous lateral bracts; stipules normally $1.5-2.5 \mathrm{~cm}$ long

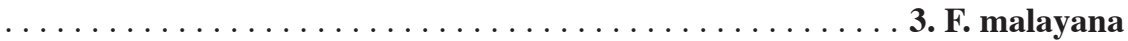

b. Fig receptacle without or with one or few lateral bracts; stipules normally $0.5-1.5$

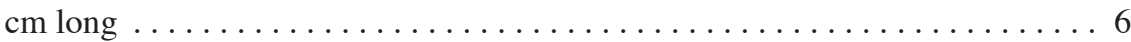

6a. Fig receptacle densely hairy; lamina \pm scabrous beneath and above

5. F. ridleyana

b. Fig receptacle subglabrous; lamina smooth.

4. F. ribes

\section{Ficus beccarii King}

The description as presented in Flora Malesiana (Berg \& Corner (2005) 398) does not need improvement.

The species is now known in Thailand as well; both in Peninsular Malaysia and Thailand the narrow-leaved form of the species is represented.

\section{Ficus heterostyla Merr.}

Ficus heterostyla Merr. (1942) 158. - Type: Pételot 2681 (holo A), Vietnam, Toi Nguyen, Phan Mê. Ficus hispida L.f. var. badiostrigosa Corner (1960) 53; Chantarasuwan \& Kumtong (2005) 81, t. 2, 5, 6. - Type: Poilane 11134 (holo P), Vietnam, Quang Tri, Dong co Pat.

Shrub or tree up to 5(-8) m tall. Leafy twigs $2.5-10 \mathrm{~mm}$ thick, whitish puberulous, intermixed with patent dark brown to purplish longer hairs, usually with pairs of nodal waxy glands on the nodes; internodes hollow; periderm sometimes flaking off. Leaves (sub) opposite or distichous; lamina elliptic to subovate, $5.5-27$ by $2-11 \mathrm{~cm}$, symmetric or slightly asymmetric, chartaceous, apex acuminate, base rounded to truncate to obtuse, margin dent(icul)ate at least towards the apex; upper surface whitish hirtellous to hispidulous, scabrous, lower surface whitish puberulous to subtomentose on the veins, on the main veins intermixed with longer patent to \pm appressed dark brown to purplish hairs, scabridulous, cystoliths only beneath; lateral veins (4-)6-8 pairs, the basal pair usually branched, 1/10-1/6 the length of the lamina, other lateral veins often branched or furcate away from the margin, tertiary venation scalariform, \pm prominent beneath; waxy glands of lateral vein in the middle of the lamina, minute (or absent); petiole 1-6 cm long, whitish puberulous, intermixed with long patent dark brown to purplish hairs, the epidermis flaking off; stipules $0.5-2 \mathrm{~cm}$ long, brown (sub) sericeous, caducous. Figs on branched or unbranched rooting stolons, 2-4 $\mathrm{m}$ long with up to $10 \mathrm{~cm}$ long internodes, mostly arising from the base of the trunk, sometimes not only 
arising from the base of the trunk but also higher on; peduncle $0.1-0.3 \mathrm{~cm}$ long; basal bracts 3, verticillate, 1-2 $\mathrm{mm}$ long; receptacle subglobose, $0.8-1.7 \mathrm{~cm}$ diam. when dry, up to $1.6-2.2 \mathrm{~cm}$ diam. when fresh, non-stipitate or up to $0.5 \mathrm{~cm}$ long stipitate, faintly ribbed, dark brown hirtellous, without lateral bracts, orange red to brownish at maturity, apex convex, ostiole c. $2 \mathrm{~mm}$ diam., surrounded by 5 apical bracts; internal hairs absent.

Distribution - Thailand, Laos, Cambodia, Vietnam.

Habitat - Evergreen forest, often secondary growth, at low altitudes.

Notes -1 . The species is related to $F$. hispida L.f. from which it differs in the stoloniflory, the dark brown indumentum on leafy twigs and other parts, the smaller fig receptacles without lateral bracts, persistent indumentum turning mostly brownish at maturity. At least in the region where the two species co-occur, F. hispida is predominantly cauliflorous with sometimes short (up to $40 \mathrm{~cm}$ long) fig-bearing branchlets at the base of the trunk, the figs have longer peduncles, and the receptacles bear (mostly) lateral bracts and turn yellow at maturity. However, dark brown to brownish (patent or appressed) indumentum is found in collections of F. hispida from Sri Lanka, South India and South China and that indumentum is apparently associated with stoloniflory. This form of $F$. hispida differs from $F$. heterostyla on the (usually) obovoid to pyriform receptacle with lateral bracts and figs ripening yellowish and in the peduncles longer than $0.3 \mathrm{~cm}$. The figs may also be borne on the trunk on short branchlets and stolon-like branches may not bear figs at all. The considerable variation of $F$. hispida in continental Asia needs further attention.

2. The type of F. hispida L.f. var. rubra Corner (1960: 54) from Vietnam, Thu Inh, $\mathrm{N}$ of Koutume, Poilane 32047 (holo P; iso L) of which the indumentum is whitish, matches the brown-hairy material described above in most other features and is probably a white-hairy form as occurs in other brown-hairy Sycocarpus species; the figs are or become glabrous.

3. This species shows also similarities to F. ridleyana, as in the rather small globose receptacle without lateral bracts and in the indumentum. It is distinct in the frequently opposite leaves, usually with a slightly asymmetric lamina without a cordate base at the broad side; moreover, the acumen of the lamina is shorter.

4. The following collections are known from Thailand (Chachoengsao, Chantaburi, Chonburi, Nakhon Nayok, Phangnga, Petchaburi and Trat Provinces): Van Beusekom et al. 3218 (AAU, L); Chantarasuwan 020240, 090301 and 2002-0420 (THNHM); Collins s.n. (BK); Kerr 9281 (BK, L); K. Larsen et al. 31061 (AAU); Maxwell 72-469 (AAU), 76-382 (AAU, BK, L), 01-306 (L); Murata T17420 (BKF); Phengklai 12622 (BKF); Rønsted et al. 541 (AAU).

\section{Ficus malayana C.C. Berg \& Chantarasuwan, stat. \& nom. nov.}

Based on: Ficus uncinata (King) Becc. var. strigosa Corner (1960) 59; Corner (1933) 17, f. 5-7 (as F. geocarpa). - Type: Corner SING 25946 (holo SING; iso K), Peninsular Malaysia, Bukit Kajang, Sungai Nipoh, Kenaman, 29 June 1932.

Ficus uncinata (King) Becc. var. truncata Corner (1960) 59. - Type: Corner 5329 (iso K), Brunei, S. Belalong, Feb. 1959.

Ficus uncinata (King) Becc. var. subbeccarii Corner (1962) 401. - Type: Corner 1619 (holo K), Sabah, Mt Kinabalu, 1200 m, 4 Aug. 1961. 
Shrub or tree up to $10 \mathrm{~m}$ tall. Leafy twigs $2-4 \mathrm{~mm}$ thick, \pm angular to subterete, brown(ish) hirtellous to subhirsute or strigillose with hairs all of similar length, sometimes intermixed with sparse shorter hairs, the long patent hairs with swollen bases, and mostly (re)curved; nodal waxy glands absent or present; internodes hollow; periderm persistent. Leaves (sub) distichous; lamina oblong to subobovate, (9-)15-30(-45) by (3-)6-17 cm, asymmetric, chartaceous, apex acuminate, base cuneate to cordate at the broad side, the lobe not covering part of the petiole (and leafy twig), cuneate to subcordate at the narrow side, margin denticulate (to dentate) at least towards the apex or (sub)entire; upper surface brownish hirtellous to hispidulous or appressed-puberulous, sometimes only on the midrib, \pm scabrous to smooth, lower surface brownish hirtellous or strigillose to appressed-puberulous on the veins, the hairs mostly all of similar length, sometimes intermixed with sparse shorter hairs, scabridulous, cystoliths only beneath; lateral veins (5-) 6-7 or 8-10 pairs, the basal pair (at least) at the broad side branched (or unbranched), none or one or two of the others furcate away from the margin, tertiary venation scalariform; waxy glands in the axils of some lateral veins in the middle part of the lamina, small; petiole $0.5-1.5(-2.5) \mathrm{cm}$ long, brownish hirtellous to subhirsute or appressed-puberulous, the hairs usually of similar length, the epidermis persistent; stipules 1-2.5 cm long, brownish hirtellous to substrigose or appressed-puberulous, caducous or subpersistent. Figs on branched, up to $10 \mathrm{~m}$ long, rooting stolons arising from the base of the trunk (or 1.5-2 $\mathrm{m}$ from the base) and with up to $10 \mathrm{~cm}$ long internodes; peduncle 0.1-0.4 cm long; basal bracts 3-6, (sub)verticillate, 2-4 $\mathrm{mm}$ long, \pm appressed; receptacle subglobose, $1.5-2(-3) \mathrm{cm}$ diam. when dry, $3-3.5 \mathrm{~cm}$ diam. when fresh, brown puberulous to hirtellous, with numerous appressed lateral bracts, these whitish to brownish appressed-puberulous to strigillose, ochraceous at maturity, apex convex to flat; ostiole $2-3 \mathrm{~mm}$ diam., more or less hidden in the indumentum, surrounded by 3-5 apical bracts; internal hairs absent. Long-styled flower with glabrous style and the perianth absent.

Distribution - Thailand (peninsular), Sumatra (only Lingga Islands), Peninsular Malaysia, Borneo: Brunei, Kalimantan, Sabah, Sarawak.

Habitat - Evergreen forest, at altitudes up to $1200 \mathrm{~m}$.

Notes -1 . Two forms can be distinguished within the species:

- form a: with patent hairs, as on the leafy twigs; it occurs throughout the range of the species and comprises the type of $F$. uncinata (King) Becc. var. strigosa.

- form b: with appressed hairs, as on the leafy twigs; it is limited to Borneo and comprises the types of $F$. uncinata var. subbeccarii and var. truncata.

2. The presence of patent and appressed hairs on various parts is found in several (stoloniflorous) species, including $F$. vrieseana Miq.

3. In material from Thailand, Sumatra and Peninsular Malaysia, the margin of the lamina is denticulate (to dentate), often from the base to the acumen and none of the lateral veins above the basal ones is furcate away from the margin. In Borneo, the margin of the lamina is entire to only (faintly) denticulate in the uppermost part and often one (or two) lateral veins above the basal ones furcate away from the margin. Moreover, the number of lateral veins is smaller, usually 6 or 7 pairs, whereas 8 pairs or more elsewhere.

4. Other collections belonging to the forms a and b of this species: Thailand: Chantarasuwan 2003-0029 (THNHM); Peninsular Malaysia: Corner SING26040 
(K, SING); Gilliland 695 (KEP, SING); Poore 708 (K); Ridley 11036 (SING); Saw FRI 36211 (K, KEP); Sinclair 9980 (SING); Sumatra: Teijsmann 7083 (L); Brunei: type 3; Kalimantan: Church et al. 493 (L); Laman et al. 1233 (L); Veldkamp 8379 (L); Weiblen et al. 883 (MIN) and 888 (L, MIN); Sarawak: Brünig S 11951 (K, L); Chai S 34012 (L); Eja S 56395 (L); Lee S 43240 (K, L); Sabah: Chew et al. 666 and 2649 (L); Corner 2541 (K (type), L).

\section{Ficus ribes Reinw. ex Blume}

Ficus ribes Reinw. ex Blume (1825) 463. - Covellia ribes (Reinw. ex Blume) Miq. (1859) 325; (1861) 434.

Covellia paniculata Miq. (1848) 467.

Ficus arfakensis King (1888b) 104, t. 133

Ficus scortechinii King (1888b) 112, t. 147.

Ficus aruensis King (1888b) 175, t. 222.

Ficus fasciculata King (1888a) 524.

Ficus staphylosyce Ridl. (1924) 301; (1925) 334.

Ficus bartlettii Merr. (1934) 153.

Ficus yatesii Merr. (1934) 154, t. 18.

Ficus hylophila Lauterb. \& K. Schum. (1901) 283.

Ficus stenothyrsa Lauterb. \& K. Schum. (1901) 285.

Ficus palustris Lauterb. \& K. Schum. (1901) 288.

Ficus tristipula Warb. (1905) 249.

The description of the species as presented in Flora Malesiana remains largely unchanged, with the exception of the distribution of cystoliths in the lamina. They occur either both above and beneath or only beneath material. The two morphs have been recognized as species: F. ribes and F. scortechinii (see Berg \& Corner (2005) 446, 451). Re-examination of material on behalf of the treatment for the Flora of Thailand led to the decision to unite them. The presence of cystoliths in the upper surface of the lamina may vary from abundant to (nearly) absent or cystoliths may even occur only above. Material with cystoliths on both sides is predominant in Sumatra and Java, rare in the Malay Peninsula and Thailand. The decision to unite the material under two species names implies that also F. arfakensis from the Moluccas, New Guinea and the Solomon Islands (see Berg \& Corner (2005) 397) needs to be included in the species due to lack of satisfactory differentiating morphological characters. The consequence is establishment of a clearly disjunct species, rare in the genus.

In Thailand (and also always? in Peninsular Malaysia) the figs are cauliflorous, mostly born on branchlets at the base of the trunk, often also partly in the soil. In Sumatra and in Java the fig-bearing branches often become stolon-like, up to $1 \mathrm{~m}$ long, and the fig receptacle can be larger, up to c. $1.5 \mathrm{~cm}$ in diam. when dry and (also) depressed-globose.

Distribution - Myanmar, Malay Peninsula, Sumatra, Java, Moluccas, New Guinea.

\section{Ficus ridleyana C.C. Berg \& Chantarasuwan, nom. \& stat. nov.}

Based on: Ficus vrieseana Miq. forma obliqua Corner (1960) 50. - Type: Corner SING 26031 (holo SING; iso K), Peninsular Malaysia, Negri Sembilan, Bukit Tangga, 29 Oct. 1932.

Shrub or tree up to $5 \mathrm{~m}$ tall. Leafy twigs $2-4 \mathrm{~mm}$ thick, \pm angular to subterete, (dark) brown strigose to hirsute, the long hairs intermixed with much shorter whitish hairs; 
nodal waxy glands (always?) absent; internodes hollow; periderm persistent. Leaves (sub)distichous; lamina elliptic to subobovate, (2-)9-40 by (1-)4-18 cm, asymmetric, chartaceous, apex acuminate to caudate, base cuneate to cordate at the broad side, cuneate to obtuse at the narrow side, margin denticulate to dentate; upper surface brown puberulous to hispidulous, \pm scabridulous, lower surface (dark) brown (sub) strigose to hirsute on the main veins to whitish puberulous to subhispidulous on the smaller veins, the long hairs intermixed with much shorter whitish hairs, \pm scabrous, cystoliths only beneath; lateral veins 7-9 pairs, most of them furcate or branched, tertiary venation scalariform; waxy glands in the axils of some lateral veins in the middle part of the lamina, and in furcations of lateral veins, small; petiole $0.8-2 \mathrm{~cm}$ long, (dark) brown strigose to hirsute, the long hairs intermixed with much shorter whitish hairs, the epidermis persistent; stipules $0.5-1.5(-2.5) \mathrm{cm}$ long, (dark) brown hirsute to strigose to partly brown appressed puberulous, caducous. Figs on branched, up to 2 (or more) $\mathrm{m}$ long, rooting stolons arising from the base of the trunk and with up to $16 \mathrm{~cm}$ long internodes; peduncle $0.2-0.5 \mathrm{~cm}$ long; basal bracts 3 , verticillate, c. $2 \mathrm{~mm}$ long, appressed; receptacle subglobose, $0.8-1.3 \mathrm{~cm}$ diam. when dry, $1.5-2 \mathrm{~cm}$ diam. when fresh, densely brown puberulous to hirtellous, the indumentum persistent, without lateral bracts, colour at maturity unknown, apex convex, ribbed towards the ostiole; ostiole c. $3 \mathrm{~mm}$ diam., surrounded by apical bracts; internal hairs absent. Long-styled flower with hairy style and the perianth (very) short collar-shaped (to absent?).

Distribution - Thailand and Peninsular Malaysia.

Habitat - Evergreen forest, at altitudes up to c. $1300 \mathrm{~m}$.

Notes -1 . This species is closely related to $F$. vrieseana Miq. (including the type of $F$. chamaecarpa Ridl.) from Sumatra and Java from which it differs in the shorter stipules, $0.5-1.5 \mathrm{~cm}$ on the leafy twigs and c. $0.5 \mathrm{~cm}$ long on the stolons (vs $1-2.5 \mathrm{~cm}$ and c. $1 \mathrm{~cm}$ long, respectively, in F. vrieseana), the shorter (c. $2 \mathrm{~mm}$ long) and appressed basal bracts (vs 2-3 mm long and patent basal bracts) and the more pronouncedly asymmetric lamina; probably also in the absence of nodal glands and in the persistence of hairs on the fig receptacle.

2. The fig receptacle and flowers are depicted in Corner (1933) fig. 10 and 11.

3 . It can be distinguished from the sympatric $F$. malayana in the indumentum on vegetative parts consisting of hairs of different length and the long hairs mostly dark brown to almost blackish and in the absence of lateral bracts.

4. It differs from F. beccarii, e.g., in the dentate margin of the lamina, the caducous stipules and the absence of lateral bracts.

5. Ficus semicordata differs, e.g., in the more numerous lateral veins, 9-15 pairs, with conspicuous waxy glands in the axils of the lateral veins at the broad side of the lamina, perianth of pistillate flowers well-developed, styles glabrous and lateral bracts often present on the fig receptacle.

6. Other collections belonging to this species: Thailand: Chantarasuwan 2003-0005 (THNHM); Peninsular Malaysia: Chew et al. 109 (K, SING); Hume 9544 (SING); Lambert A 33 (KEP); Ridley 2588 (SING); Shah MS 1610 (K, KEP, SING).

\section{Ficus semicordata Buch.-Ham. ex Sm.}

The description and distribution are still as presented in Flora Malesiana (Berg \& Corner (2005) 382). 


\section{Stoloniflorous species in Borneo}

In the wake of the revision of the stoloniflorous species found in Thailand and Peninsular Malaysia, the same group of species in Borneo had to be re-examined which leads to the conclusion that F. uncinata, as defined by Corner (1960) and as such adopted for the Flora Malesiana treatment (Berg \& Corner, 2005) comprises four species: 1) Ficus malayana, treated above, comprising some of the collections listed under F. uncinata var. strigosa (Corner, 1960) and the types of var. subbeccarii (Corner (1962) and var. truncata Corner (1960); 2) Ficus uncinata s.str., comprising most of the collections identified as F. uncinata var. uncinata and the type of var. gracilis; 3) Ficus megaleia Corner $(1960,1962)$, also comprising some of the collections identified as $F$. uncinata var. pilosior Corner (1960) and var. strigosa Corner (1960); 4) an undescribed species, F. bukitrayaensis C.C. Berg, comprising for the greater part more recent collections, not yet listed by Corner (1960), and F. uncinata var. parva Corner (1960). Also the treatment of F. uncinata in the Tree Flora of Sabah and Sarawak (Kochummen, 2000) indicated heterogeneity. The key also comprises $F$. geocharis Corner, $F$. stolonifera King and $F$. subterranea Corner; in all these species the long-styled flower lacks a perianth and has a glabrous style, except for F. stolonifera with a hairy style and a short collar-shaped perianth. Ficus treubii King is also included in the key as it can be stoloniflorous and has the fig receptacle usually with 1 or 2 lateral bracts.

\section{KEY TO BORNEAN STOLONIFLOROUS SPECIES WITH LATERAL BRACTS}

1a. Margin of the lamina (also of the acumen) entire or subentire $\ldots \ldots \ldots \ldots 2$

b. Margin of the lamina denticulate or dentate, at least towards the apex or on the

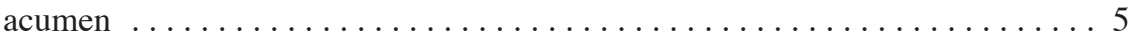

2a. Lamina often scabridulous, upper surface hairy $\ldots \ldots \ldots \ldots \ldots \ldots \ldots$

b. Lamina smooth, upper surface glabrous $\ldots \ldots \ldots \ldots \ldots \ldots \ldots \ldots$

3a. Indumentum on leafy twigs, petiole, and lamina beneath predominantly consisting of hairs with similar length; base at the broad side of the lamina not auricled . . . .

3. F. malayana

b. Indumentum on leafy twigs, petiole and (main) veins of the lamina beneath consisting of \pm dense whitish minute hairs and much longer brown(ish) hairs; base at the broad side of the lamina auricled $\ldots \ldots \ldots \ldots \ldots \ldots \ldots \ldots$. geocharis

4a. Hairs on leafy twigs and stipules whitish, apex of lamina acuminate . . . . . .

F. subterranea

b. Hairs on leafy twigs and stipules yellowish; apex of lamina caudate (the acumen to filiform $) \ldots \ldots \ldots \ldots \ldots \ldots \ldots \ldots \ldots \ldots \ldots \ldots \ldots \ldots \ldots \ldots \ldots \ldots$. Feccarii

5a. Lamina smooth above, upper surface glabrous; lateral bracts 1 or 2 . . F . treubii

b. Lamina scabrous to scabridulous, at least above and/or usually more than 2 lateral

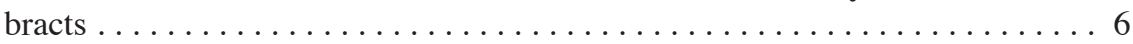

6a. Lamina slightly unequilateral at the base; swollen bases of long hairs usually echinate; bracts $1.5-2 \mathrm{~mm}$ long $\ldots \ldots \ldots \ldots \ldots \ldots \ldots \ldots \ldots \ldots$ stolonifera

b. Lamina strongly unequilateral at the base; swollen bases of long hairs not echinate;

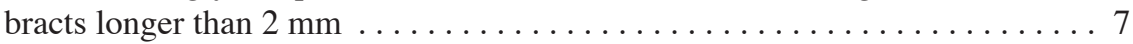


7a. Lateral veins 3-6(-7) pairs; fig receptacle brown hairy, lateral bracts \pm patent . . 9. F. uncinata

b. Lateral veins 6-15(-24) pairs; fig receptacle glabrous or sparsely hairy, or if brown hairy, then the lateral bracts \pm appressed $\ldots \ldots \ldots \ldots \ldots \ldots$

8a. Indumentum on leafy twigs, petiole and lamina beneath predominantly consisting of hairs with similar length; lateral veins above the basal pair not or sometimes one or two furcate away from the margin; fig receptacle densely brown hairy . .

3. F. malayana

b. Indumentum on leafy twigs, petiole and (main) veins of the lamina beneath consisting of \pm dense whitish minute hairs and much longer brown(ish) hairs; most lateral veins (others than the basal ones) branched or furcate away from the margin; figs receptacle subglabrous (but bracts white puberulous and/or brown strigillose

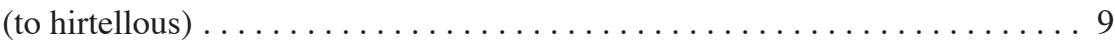

9a. Petiole $0.7-3 \mathrm{~cm}$ long; lateral veins frequently furcate away from the margin or branched; narrow side of the base of the lamina often obtuse or cordate . . . . . .

8. F. megaleia

b. Petiole $0.3-0.7(-1) \mathrm{cm}$ long; lateral veins not or sometimes furcate away from the margin; narrow side of the base of the lamina cuneate . . . . . . . 10

10a. Fig receptacle glabrous and bracts glabrous or with a few hairs; acumen of the lamina 1.5-2 cm long; lobe at the base of the lamina not auricled ........

7. F. bukitrayaensis

b. Figs receptacle and bracts brown hairy; acumen of the lamina (2-)3-6 cm long; lobe at the base of the lamina auricled $\ldots \ldots \ldots \ldots \ldots \ldots \ldots$. geocharis

\section{Ficus bukitrayaensis C.C. Berg, spec. nov. - Fig. 1}

Fico geochariti similis, fici receptaculo glabro maturitate albescenti, folii lamina basi lobo non-auriculato, acumine breviore differt. - Typus: Veldkamp 8601 (holo L), Indonesia, Kalimantan, Bukit Raya, Batu Badinding, KCT, 50 m, 8 Feb. 1983.

Ficus uncinata (King) Becc. var. parva Corner (1960) 59. - Type: Corner s.n. (iso K), Brunei, Andulau Forest, Feb. 1959.

Tree up to 6(-8) $\mathrm{m}$ tall. Leafy twigs $2-3 \mathrm{~mm}$ thick, sparsely to rather densely whitish to brownish puberulous and brown hirtellous to subhirsute, the longer hairs with \pm swollen bases, (glabrescent); nodal waxy glands absent or present; internodes solid; often with minute axillary buds; periderm persistent. Leaves (sub)distichous; lamina elliptic, (3-)13-25(-30) by (1-)3-7(-9) cm, asymmetric, chartaceous, apex acuminate, acumen $1.5-2 \mathrm{~cm}$ long, base cuneate to cordate at the broad side, sometimes partly covering the petiole, cuneate at the narrow side, margin denticulate; upper surface sparsely to densely whitish hispidulous and brownish puberulous to hirtellous to strigillose, the longer hairs with swollen bases, \pm scabridulous to smooth, lower surface sparsely to densely (mostly minutely) whitish puberulous and brown(ish) hirtellous, the longer hairs with \pm swollen bases, \pm scabridulous to smooth, cystoliths only beneath; lateral veins (2-)6-10 pairs, the basal pair at the broad side branched, none (or some) of the others furcate away from the margin, tertiary venation scalariform; waxy glands in the axils of some lateral veins in the middle part of the lamina, small; petiole $0.3-0.7$ $\mathrm{cm}$ long, minutely whitish puberulous and brown(ish) hirtellous, the longer hairs with 


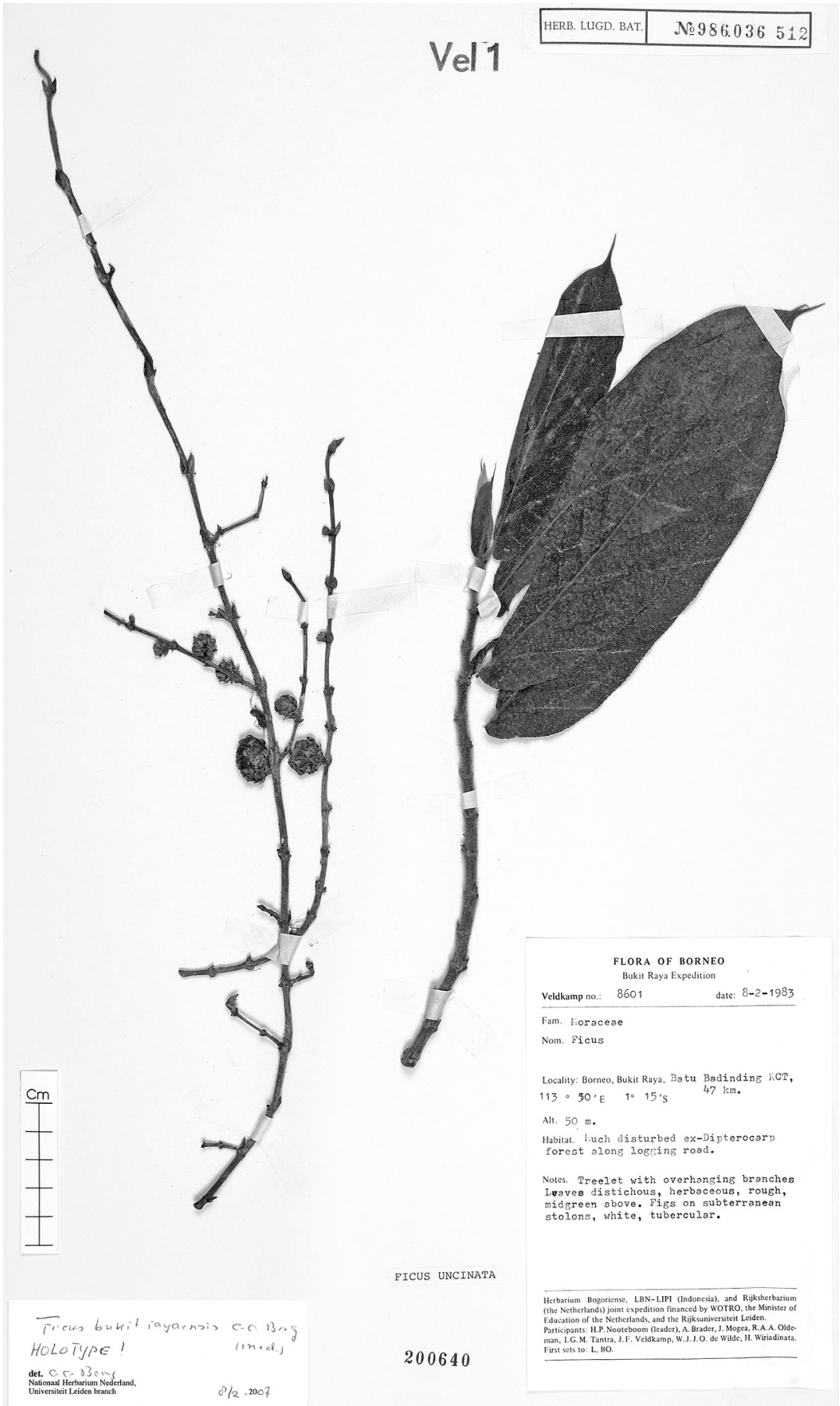

Fig. 1. Ficus bukitrayaensis C.C. Berg. Leafy twig and fig-bearing stolons (Veldkamp 8601, L). Indonesia, Kalimantan, Bukit Raya, Batu Badinding, 50 m, 8 Feb. 1983. 
\pm swollen bases, the epidermis persistent; stipules (1-) $1.5-4 \mathrm{~cm}$ long, brown hirtellous to substrigillose on the keel, subpersistent or caducous. Figs on branched, 2-4 $\mathrm{m}$ long, rooting stolons arising from the base of the trunk and with up to $3.5 \mathrm{~cm}$ long internodes; peduncle $0.1-0.3 \mathrm{~cm}$ long; basal bracts $3-6$, (sub)verticillate to scattered on the peduncle, 1-3 mm long, \pm appressed to \pm patent; receptacle subglobose, $1-1.5$ cm diam. when dry, (sub) glabrous, with numerous appressed (or reflexed) lateral bracts without (or with a few hairs), (pinkish) white (or partly to entirely green) at maturity, apex convex to flat; ostiole c. $4 \mathrm{~mm}$ diam., covered with several apical bracts; internal hairs absent. Long-styled flower with glabrous style and the perianth absent.

Distribution - Borneo: Sabah, Sarawak, Kalimantan.

Habitat - Evergreen forest, at low altitudes.

Notes -1 . This species shows close affinities to $F$. geocharis, from which it differs in the (sub)glabrous fig receptacle, shorter and glabrous bracts, the shorter acumen of the lamina (1.5-2 vs (2-)3-6 cm) and the different base of the broad side of the lamina: not a narrow auriculate strip along the petiole.

2. It also resembles the small-leaved form of $F$. megaleia, from which it differs in the shorter petiole, mostly also in the smaller lamina, and, moreover, in the shorter and glabrous bracts of the fig.

3. The type of Ficus uncinata var. parva (Corner, 1960) and Harrison 0197 from Sarawak, Lambir Hills National Park are distinct in the predominantly white colour of the indumentum on vegetative parts.

4. The colour of the mature figs is mostly white or whitish or (partly) greenish if exposed on the soil surface. However, some labels describe the figs (partly) red or maroon.

5. Additional collections belonging to this species: Kalimantan: De Vogel 734 (L); Endert 2592 (L); Kartawinata 700 (L); Veldkamp 8169 (L); Weiblen et al. 886 (L); Sabah: Amin \& Thomas SAN 117326 (L); Sarawak: Chai S 34003 (L); Harrison 52, 179, 197, 523 (RDH); Sibat al Luang S 24304 (K, L).

6. The collections Ambriansyah 513 (L) and Keßler et al. 943 (L) from E Kalimantan largely match the collections cited above, but differ in the presence of some lateral veins furcate away from the margin and the presence of some hairs on the lateral bracts of the fig.

7. Collection Davies et al. 99168 (L) from Sabah matches the typical material of this species in most features, but the label tells that the figs are borne on up to $3 \mathrm{~m}$ long hanging shoots and the figs are purplish.

Ficus malayana C.C. Berg \& Chantarasuwan

See for description etc. above under number 3.

\section{Ficus megaleia Corner}

Ficus megaleia Corner (1960) 57; C.C. Berg \& Corner (2005) 433. - Type: Corner 5301 (holo CGE), Brunei, Ulu Belalong, Feb. 1959.

Ficus uncinata (King) Becc. var. pilosior Corner (1960) 59. - Type: Corner 5302 (holo CGE; iso K, L), Malaysia, Sabah, S. Belalong, Feb. 1959.

Ficus megaleia Corner var. multinervia Corner (1962) 400. - Type: Chew et al. RSNB 970 (holo K; iso L), Malaysia, Sabah, Mt Kinabalu, 900 m, 25 July 1961. 
Ficus megaleia Corner var. subuncinata Corner (1962) 400. - Type: Chew et al. RSNB 1567 (holo K; iso L), Malaysia, Sabah, Mt Kinabalu, 1500 m, 31 July 1961.

Shrub or tree up to $5(-10$ ?) $\mathrm{m}$ tall. Leafy twigs $2-7 \mathrm{~mm}$ thick, minutely whitish to brownish puberulous and brown hirtellous to subhirsute or the hairs predominantly of similar length, the longer with \pm swollen bases; nodal waxy glands absent or present; internodes hollow; periderm persistent. Leaves (sub)distichous; lamina oblong, (3-) $15-50(-100)$ by $(2-) 6-15(-35) \mathrm{cm}$, asymmetric, chartaceous, apex (sub)acuminate, base cuneate to cordate at the broad side, the lobe partly covering the petiole and leafy twig or not, rounded to cordate at the narrow side, margin denticulate to dentate, at least (the apex of) the acumen; upper surface sparsely to densely whitish hispidulous and brownish hirtellous to strigillose or the hairs predominantly of similar length, the longer hairs with swollen bases, \pm scabrous, lower surface sparsely to densely (mostly minutely) whitish puberulous and brown(ish) hirtellous to subhirsute, the longer hairs with \pm swollen bases, \pm scabrous (to almost smooth), cystoliths only beneath; lateral veins (6-)8-15(-24) pairs, the basal pair branched, several (or most) of the others branched or furcate away from the margin, tertiary venation scalariform; waxy glands in the axils of some lateral veins in the middle part of the lamina or also in furcations of lateral veins, small; petiole $0.7-3 \mathrm{~cm}$ long, minutely whitish puberulous and brown(ish) hirtellous to subhirsute or the hairs predominantly of similar length, the longer hairs with \pm swollen bases, the epidermis persistent; stipules (1-)1.5-5.5(-10) cm long, whitish appressed-puberulous and brown hirtellous to strigillose to subsericeous on the keel, caducous or subpersistent. Figs on branched, up to $10 \mathrm{~m}$ long rooting stolons arising from near the base of the trunk and with up to $8 \mathrm{~cm}$ long internodes (or on branched leafless branchlets on the trunk and main branches); peduncle $0.1-0.5(-1.3) \mathrm{cm}$ long; basal bracts 3-5, (sub)verticillate to scattered on the peduncle, 3-7 mm long, \pm appressed; receptacle subglobose to obovoid (to subpyriform), 1-2.5(-3) cm diam. when dry, 4-5 $\mathrm{cm}$ diam. when fresh, subglabrous or (sparsely) whitish to brownish puberulous, with numerous appressed lateral bracts, these white puberulous and/or brown strigillose (or subglabrous), red (to purplish) at maturity, apex convex to flat (to slightly concave); ostiole 3-5 mm diam., surrounded by 5 or 6 incurved or straight apical bracts; internal hairs absent. Long-styled flower with glabrous style and the perianth absent.

Distribution - Borneo: Brunei, Sabah, Sarawak, Kalimantan.

Habitat - Evergreen forest at altitudes up to c. $2000 \mathrm{~m}$.

Notes -1 . The species comprises two main forms which differ in size of the lamina, length of the petiole and shape of the lobe of the base of the lamina at the broad side:

- form a: lamina mostly $35-50 \mathrm{~cm}$ long, petiole mostly $1.5-3 \mathrm{~cm}$ long, lobe of the base of the lamina at the broad side mostly partly covering the petiole and leafy twig;

- form b: lamina mostly $15-30 \mathrm{~cm}$ long, petiole mostly $0.7-1.5 \mathrm{~cm}$ long, lobe of the base of the lamina mostly not covering the petiole and/or reaching the leafy twig. The collections made can be roughly sorted on the basis of these differences. Although the majority of collections which can be included in form a are made on Mt Kinabalu at altitudes between 1200-2000 m, the two forms cannot be distinguished satisfactorily on geographical nor on ecological criteria. 
2. In the majority of the collections the hairs on leafy twig, petiole, and main veins beneath are clearly different in length (and colour), but in some, as Beccari 2798 (L), Chew 662 (K, L), De Vogel 756 (K, L), Reksodihardjo 139 (K, L), the indumentum on these parts consists predominantly of hairs of similar length, resembling the indumentum of F. malayana.

3. Collection Mabberley 1704 (L) probably belongs to the small-leaved form of this species. It deviates in the appressed indumentum on leafy twig, petiole and main veins of the lamina beneath and is not included in the description as it is sterile. This type of indumentum is also found in a form of $F$. malayana.

4. Sterile material of the small-leaved form of F. megaleia can be confused with F. stolonifera; the latter is distinct by the usually echinate swollen bases of the long hairs. Additional collections belonging to this species: Brunei: Corner 5310 (L); Kalimantan: Burley et al. 581 (L); De Vogel 734 (K, L), 756 (K, L), 2116 (L); Endert 3486 (L); Hallier 2596 (L); Keßler et al. PK 2033 (K); Kostermans 10843 (L); Mahyar 912 (L); Murata et al. B 4224 (L); Nieuwenhuis 104, 1287 (L); Reksodihardjo 139 (K, L); Sabah: Clemens 30621 (L); Nooteboom 1231 (L); Saw FRI 36256 (K, L); Sarawak: Beccari 2798 (K); Chew 662 (K, L); Lee S 40005 (L), S 52589 (L).

\section{Ficus uncinata (King) Becc.}

Ficus uncinata (King) Becc. (1902) 527. - Ficus geocarpa Teijsm. ex Miq. var. uncinata King (1888b) 102, t. 129. - Type: Beccari 2458 (iso K), Borneo, without locality.

Ficus uncinata (King) Becc. var. gracilis Corner (1960) 58. - Type: Corner 5303 (iso K), Brunei, S. Belalong, Feb. 1959.

Shrub or tree up to 4(-6?) m tall, often branched near the base. Leafy twigs $2-4 \mathrm{~mm}$ thick, whitish puberulous, intermixed with mostly dark brown, sometimes whitish, much longer hairs, mostly curved upwards to appressed (or \pm retrorse) and mostly with \pm swollen bases; nodal waxy glands absent or present; internodes hollow; periderm persistent. Leaves (sub)distichous; lamina oblong to lanceolate (to subfalcate), (4-) $15-35$ by (1.5-)5-15 cm, asymmetric, chartaceous, apex acuminate to caudate, base cuneate to cordate at the broad side, the lobe often covering part of the petiole and leafy twig, cuneate to obtuse at the narrow side, margin denticulate to dentate; upper surface whitish puberulous to hispidulous, scabrous, lower surface whitish puberulous to hispidulous, on the main veins intermixed with much longer brown hairs, \pm scabrous; cystoliths only beneath; lateral veins $3-6(-7)$ pairs, the basal one at the broad side \pm branched, mostly 1 or 2 of the others furcate away from the margin, tertiary venation scalariform; waxy glands in the axils of some lateral veins in the middle part of the lamina and also in furcations of lateral veins; petiole $0.5-1.5(-3) \mathrm{cm}$ long, whitish puberulous, intermixed with mostly dark brown, sometimes whitish much longer hairs, the epidermis persistent; stipules (1-)1.5-3 cm long, whitish appressed-puberulous to brown or whitish strigose on the keel, caducous or subpersistent. Figs on branched 2-4 $\mathrm{m}$ long rooting stolons arising from the base of the trunk and with up to $10 \mathrm{~cm}$ long internodes; peduncle $0.1-0.4 \mathrm{~cm}$ long; basal bracts 3-5, (sub) verticillate, 1-3 mm long, \pm patent; receptacle subglobose, (1-)1.5-2(-3) cm diam. when dry, densely brownish puberulous to hirtellous (or to subglabrous), with several lateral bracts, these patently curved, 3-5 mm long, often slightly broadened at the apex, receptacle dark 
red to purplish at maturity, apex convex; ostiole 4-5 mm diam., surrounded by 5 or 6 erect to curved apical bracts; internal hairs absent. Long-styled flower with glabrous style and the perianth absent.

Distribution - Borneo: Brunei, Sarawak, Kalimantan.

Habitat - Evergreen forest, at altitudes up to c. $1100 \mathrm{~m}$.

Notes -1 . This species differs from the other species of the F. stolonifera-group, and more restricted, from the species of which the pistillate flowers lack a perianth and the long-styled flowers lack hairs on the style, in the small number of lateral veins, $3-6(-7)$ pairs, and the \pm patent lateral bracts.

2. The fig receptacle is brown hirtellous to puberulous in the majority of the collections, but in two collections, Endert 2930 (L) from E Kalimantan and Othman et al. $S 41485$ (L) from Sarawak, the receptacle is subglabrous and the bracts sparsely puberulous. Other collections belonging to this species: Brunei: type; Kalimantan: Endert 2930 (L); Koyama \& Noma K 3863 (L); Nieuwenhuis 292 (L); Veldkamp 8361 (L); Winkler 349 (L); Sarawak: Anderson S 27359 (L); Banyeng S 46037 (L); Brooke 10249, 10522 (L); Chai et al. S 33227 (L); Chin 2838 (L); Lee S 40019 (L); Paie S 42540 (K, L); Primack S 42430 (K, L); Othman et al. S 41485 (K, L); Yii et al. $S$ 40549, S 43160, S 46034 (L).

\section{ACKNOWLEDGEMENTS}

Some of the data for this study have been acquired during a visit to herbarium E(dinburgh), financed by the European Commission's Research Infrastructure Action via the SYNTHESYS Project.

Dr. R.D. Harrison (Kyoto) commented on the manuscript and provided additional data. Mrs. M. Thomas (Kew) assisted by supplying information about several collections. Dr. J.F. Veldkamp (Leiden) translated the diagnosis into Latin.

\section{REFERENCES}

Beccari, O. 1902. For. Borneo. Firenze.

Berg, C.C. \& E. J.H. Corner. 2005. Moraceae - Ficus. Flora Malesiana, Ser. I, 17/2. Leiden.

Blume, C.L. 1825. Bijdragen tot de Flora van Nederlandsch Indië. Batavia.

Chatarasuwan, B. \& P. Kumtong. 2005. On two varieties of Ficus hispida L.f. (Moraceae) in Thailand. J. Thail. Nat. Hist. Mus. 1, 1: 79-85.

Corner, E.J.H. 1933. A revision of the Malayan species of Ficus: Covellia and Neomorphe. J. Malayan Branch Roy. Asiat. Soc. 11: 1-65.

Corner, E.J.H. 1960. Taxonomic notes on Ficus Linn., Asia and Australasia. VI. Subg. Ficus sect. Sycocarpus Miq. Gard. Bull. Singapore 18: 36-64.

Corner, E.J.H. 1962. Taxonomic notes on Ficus L., Asia and Australasia. Addendum II. Gard. Bull. Singapore 19: 385-401.

King, G. 1888a. Ficus. In: J.D. Hooker \& T. Thomson (eds.), Flora of British India 5: 494-537. London.

King, G. 1888b. The species of Ficus of the Indo-Malayan and Chinese countries. Ann. Roy. Bot. Gard. (Calcutta) 1, 2: 67-185, t. 88-232.

Kochummen, K. M. 2000. Ficus. In: E. Soepadmo \& L.G. Saw (eds.), Tree Fl. Sabah \& Sarawak 3: 213-317. Kuala Lumpur.

Lauterbach, K. \& K. Schumann. 1901. Ficus. In: K. Schumann \& K. Lauterbach (eds.), Die Flora der deutschen Schutzgebiete in der Südsee: 268-289. Leipzig.

Merrill, E.D. 1934. New Sumatran plants I. Pap. Michigan Acad. Sci. 19: 149-203, t. 16-35. 
Merrill, E.D. 1942. Records of Indo-Chinese plants III. J. Arnold Arbor. 23: 156-197.

Miquel, F. A.W. 1848. Prodromus monographiae Ficuum. London J. Bot. 7: 64-78, 109-116, 221-236, 425-471.

Miquel, F.A.W. 1859. Flora Indiae Batavae 1, 2. Amsterdam.

Miquel, F. A.W. 1860-1861. Flora Indiae Batavae, Supplementum primum. Prodromus Florae Sumatranae. Amsterdam.

Ridley, H.N. 1924. New Malayan plants. J. Bot. 62: 294-301.

Ridley, H.N. 1925. Fl. Malay Penins. 5. London.

Warburg, O. 1905. Ficus. In: K. Schumann \& K. Lauterbach, Nachträge zur Flora der deutschen Schutzgebiete in der Südsee: 241-251. Leipzig. 